\title{
LAS IMÁGENES COMO FENÓMENO CULTURAL: UNA NECESARIA MIRADA EN ETAPAS PARA ABORDAR LOS RETOS ACTUALES
}

\author{
Images, History and Culture. Some current challenges
}

\section{Bernardo Riego Amézaga ${ }^{\alpha}$}

Fecha de recepción: 17/07/2018 • Fecha de aceptación: 16/11/2018

Resumen. El reconocimiento de las imágenes como un fenómeno cultural constituye hoy una certeza apenas discutida, aun cuando los métodos para analizarlas en los respectivos campos de estudio de las Humanidades y de las Ciencias Sociales sigan siendo objeto de un gran debate, por la intersección de varias disciplinas que las explican de un modo divergente.

Una mirada histórica, nos permitirá entender no solo la posición cultural que han ocupado sino también las enormes fricciones entre la denominada «alta cultura» en la que se engloba nuestra cultura académica, y la cultura popular de la sociedad de las masas, que, a través de soportes como el fotograbado y el cinematógrafo, mostraron visualmente aspectos de la realidad de su tiempo a personas que apenas necesitaban valerse del texto escrito. El artículo estudia también los procesos de convergencia que se han producido en el estudio de las imágenes, los desplazamientos del análisis de las representaciones desde la Historia del Arte a otras disciplinas que han dotado a sus significados de perspectivas nuevas y de contextos mucho más precisos. Analizamos diferentes posiciones en el análisis de las imágenes y la necesidad de dotar dicho análisis de un aparato crítico que contemple también los tiempos históricos superpuestos en cada representación.

Palabras clave: Historia de las Imágenes; Análisis Cultural de las Imágenes; Educación; Sociedad e Imágenes Contemporáneas; Métodos de Análisis Iconográficos.

Abstract. The academic recognition of images as a cultural phenomenon is widely accepted today, even if the methods for analyzing them in the respective

\footnotetext{
${ }^{a}$ Departamento de Educación. Facultad de Educación. Universidad de Cantabria. Avenida de los Castros, s/n.39005 Santander. España.briego@unican.es.
}

Cómo citar este artículo: Riego Amézaga, Bernardo. «Las imágenes como fenómeno cultural: una necesaria mirada en etapas para abordar los retos actuales». Historia y Memoria de la Educación 10 (2019): 17-49 
fields of study of the Humanities and Social Sciences continue to be the object of great debate due to the intersection of several disciplines that explain them in divergent ways.

A historical perspective will allow us to understand not only the cultural position they have occupied but also the enormous frictions between the socalled "high culture» in which our academic culture is included, and the popular culture of the society of the masses, which through media formats such as photogravure and cinematography have shown visual aspects of the reality of their time to people who hardly needed to use the written text. The article also studies the processes of convergence that have taken place in the study of images and the displacements of the analysis of representations from the History of Art to other disciplines that have endowed their meanings with new perspectives and much more precise contexts. We analyze different positions in the analysis of the images and the need to provide the analysis of the images with a critical mechanism that also includes the historical times that are overlapped in each representation.

Keywords: History of Images; Cultural Analysis of Images; Education, Society and Contemporary Images; Methods of Iconographic Analysis.

\section{EL COMPLEJO ENCUENTRO ENTRE LAS IMÁGENES Y LA HISTORIA. ALGUNOS ESBOZOS INICIALES}

En estos momentos no parecer estar muy en discusión la importancia de las imágenes para construir el relato historiográfico. A muchos historiadores, formados en la tradición rankeana del documento textual y su crítica interna y externa, nos parece que el documento visual tiene muchos elementos compatibles con nuestra forma de analizar las fuentes, pero es cierto que las imágenes han formado parte de otra epistemología desde hace largo tiempo, que han sido concebidas como instrumentos expresivos más que racionales, y parece que ya existe toda una depurada disciplina que se ocupa de ellas, a la que denominamos historia del arte; y a pesar de las aparentes facilidades para entender las imágenes e insertarlas en el discurso historiográfico coherente con las fuentes escritas, las representaciones visuales presentan una serie de dificultades que finalmente son atenuadas cuando las imágenes históricas se integran en el discurso como meras ilustraciones de algún aspecto del pasado, y parecen convertirse en evidencias directas más que en textos visuales que es necesario explorar y contextualizar más allá de su propia y en ocasiones rotunda apariencia. Una práctica común de las imágenes 
en el trabajo histórico que no integran sus capacidades discursivas, sino que solo son aparentes evidencias visuales del pasado.

¿Puede servirnos la metodología de la historia del arte para interpretar las imágenes que nos ha legado el tiempo pasado? Adelanto que la respuesta que voy a dar es necesariamente ambigua, porque la historia del arte se ocupa de los autores, de las formas expresivas y estéticas que adoptan en el tiempo, de las técnicas, los soportes y los materiales para crear imágenes en un momento dado, y sobre todo de la singularidad de los artistas, con sus estilemas específicos en las obras, luego encuadradas en movimientos que las hacen reconocibles y comprensibles en una época concreta. A priori, la disciplina que estudia las imágenes desde la perspectiva artística no se ocupa demasiado ni de los contextos de producción de las obras, ni de su recepción social, aunque existen notables excepciones a esa tradición tan generalizada en la disciplina que deben ser tenidos en cuenta - cito tan solo algunos autores- como Ernest Gombrich, ${ }^{1}$ David Freedberg, ${ }^{2}$ e historiadores de la propia historia del arte como Francis Haskell, ${ }^{3}$ autor de un estudio muy relevante sobre las imágenes y su inserción en el universo epistemológico de la propia especialidad a lo largo del tiempo.

Pero en estos momentos nos encontramos ante otra evidencia que hace más complejo el uso de las imágenes en el discurso historiográfico; desde la periodización de la época contemporánea; es decir, desde el movimiento ilustrado a mediados del siglo XVIII a nuestros días, en la denominada sociedad-red, ${ }^{4}$ en la que observamos cómo la densidad de las imágenes ha aumentado de modo exponencial. Una persona que vivía hace tres o cuatro siglos contaba con muy pocos espacios para contemplar imágenes, salvo las elites a través del patronazgo cortesano y aristocrático, a las que se sumará en un momento dado la ascendente burguesía de los negocios, que disfrutaban de un número mayor, pero

\footnotetext{
1 Ernst Gombrich historiador del arte, es uno de los más conocidos representantes de la escuela iconográfica alemana. Sin duda, la mejor representación de su trabajo y pensamiento lo encontramos en Ernst Gombrich, Gombrich Esencial (Madrid: Debate, 1999).

2 David Freedberg, El poder de las imágenes (Madrid: Cátedra, 1992).

3 Francis Haskell, La historia y sus imágenes. El arte y la interpretación del pasado (Madrid: Alianza Forma, 1993).

${ }^{4}$ Manuel Castells, La sociedad red: una visión global (Madrid: Alianza Ensayo, 2006).
} 
así y todo muy limitado si lo comparamos con el consumo iconográfico actual. Clases medias, artesanos, y lo que englobamos en la imprecisa categoría de "pueblo», apenas contaban con alguna imagen de su propiedad, y si las poseían eran generalmente estampas, un mercado del que todavía nos queda mucho por entender, pero que hasta la invención de la fotografía en el siglo XIX, las estampas fueron muy importantes referentes de la realidad en un proceso de veracidad narrativa que fue forjándose lentamente desde el siglo XV hasta que la evidencia notarial de las imágenes fotográficas destruyo la reputación realista que se atribuía a los grabados.

Hay que esperar al siglo XIX en el desarrollo del Sistema Informativo liberal, y la aparición de la prensa con ilustraciones de actualidad informativa, primero dibujadas del acontecimiento o transcritas de la imagen fotográfica, para que se multipliquen a través de la imprenta una serie de imágenes utilitarias que se consideran excepcionales por lo que muestran, pero que ya no se consideran sublimes con categoría específicamente artística, como tampoco se la considerará a la propia fotografía, que será vista como un arte mecánico reproductivo de la realidad visible. En el siglo XX, la invención del fotograbado potenciará la prensa gráfica, la tarjeta postal y otros medios visuales como el cartelismo al que se sumará por otra parte el espectáculo del cinematógrafo. Por lo que hoy un historiador tiene a su disposición una gran cantidad de fuentes que no pueden entenderse ya desde las posiciones clásicas de la historiografía del arte, y se hace necesario recurrir a aproximaciones de otro tipo para poder ensamblar cada significado cultural y social de las imágenes en su sentido historiográfico preciso, que no siempre se revela de modo evidente en las propias representaciones.

En el año 2001, publiqué un trabajo que se interrogaba sobre la capacidad de las imágenes producidas en un momento determinado de convertirse en fuentes historiográficas a través de su capacidad de articularse como un texto visual que se insertarse en el análisis de un acontecimiento histórico concreto. Elegí el siglo XIX y el fenómeno de la denominada "prensa de negocio», un término acuñado por el historiador del periodismo Jesús Timoteo Álvarez, que me sigue pareciendo muy operativo. En las revistas del siglo XIX asistimos, con las ilustraciones, al nacimiento de la información gráfica de actualidad; una nueva categoría cultural creada a través del dibujo impreso periódicamente en las 
páginas de la prensa a través del grabado en madera, mientras la convicción de veracidad de las imágenes fotográficas se convertía en una verdad indiscutida en la acelerada sociedad decimonónica. ${ }^{5}$ Ese mismo año, Peter Burke, en un libro que ha tenido una enorme influencia, ${ }^{6}$ abogó por el uso de las imágenes fotográficas en la historia, además de otras muchas nuevas fuentes que fueron objeto de revisión en una segunda obra de la que fue editor ${ }^{7}$ aunque en este libro, en el capítulo referido a la Historia Visual, aparece toda la cuestión mucho más difusa.

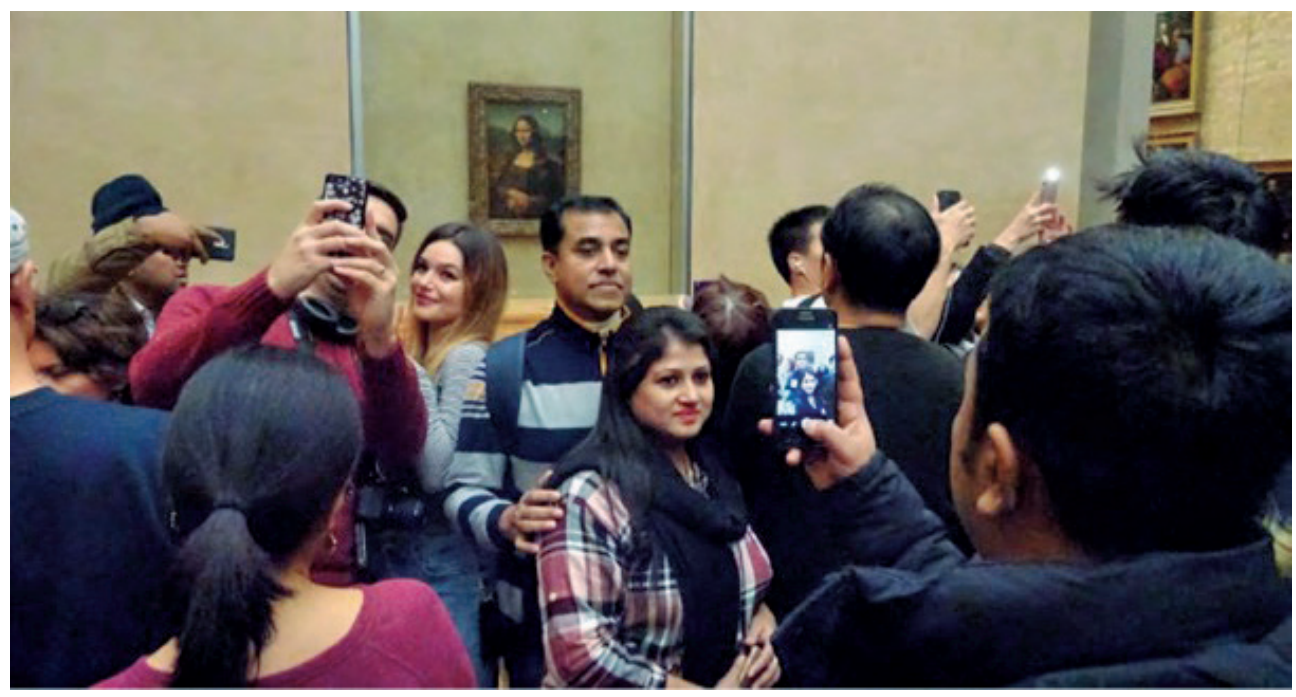

Imagen 1. Las nuevas prácticas culturales en el uso de las imágenes han desplazado tendencias históricas que en la sociedad digital es necesario analizar con otras premisas. (Fotografía de Bernardo Riego en el Museo del Louvre frente a la Monna Lisa en 2017).

¿Qué retos nos plantean las imágenes hoy a los historiadores? Estamos ante un momento en el que la iconosfera digital se ha vuelto extremadamente densa; asistimos a una época en la que las imágenes se han apoderado ya de la propia realidad inmersas en una «cultura de superficie

\footnotetext{
${ }^{5}$ Bernardo Riego, La construcción social de la realidad a través de la fotografía y el grabado informativo en la España del siglo XIX (Santander: Ediciones UC, 2001).

${ }^{6}$ Peter Burke, Visto y no visto. El uso de la imagen como documento histórico (Barcelona: Crítica, 2001).

7 Peter Burke (ed.), Formas de hacer historia (Madrid: Alianza Ensayo, 2003). El capítulo dedicado a la historia visual, en nuestra opinión un poco difuso en sus objetivos, está firmado por Ivan Gaskell y se encuentra en las páginas 221-254 en la edición que hemos manejado (2014).
} 
y del simulacro", por utilizar los términos de Umberto Eco y Jean Braudillard a los que volveremos más adelante. Ahora entender las imágenes ya no es una tarea simple, pues existen enfoques divergentes sobre cómo abordarlas metodológicamente desde campos como la comunicación, la antropología cultural o la sociología, que compiten, cuando no ignoran, la tradición de la historia del arte, hegemónica hasta la década de los años sesenta del pasado siglo en su encuentro con las imágenes. A esto se suman las nuevas posiciones culturales de la posmodernidad que niegan a la propia historia su capacidad documental, y dejan a la historiografía en uno de los muchos relatos posibles, a la que solo reconoce su capacidad literaria pero no científica. Por si todo esto fuera poco, se hace necesario entender algunas de las cuestiones que han sido las causantes de que las imágenes hayan sido ignoradas en los ámbitos académicos durante tanto tiempo para explicar el pasado, lo que nos remite a las fricciones culturales que su crecimiento tecnológico y su presencia pública suscitaron en el advenimiento de la sociedad de las masas con una alta cultura de base textual, en la que residía todo el conocimiento, que no daba valor a la prensa gráfica ni al cinematógrafo, que se resistía a entender el mundo moderno que se estaba fraguando, y en el que las imágenes ganaban poco a poco terreno a los textos escritos. Todo ello nos debe remitir a una pregunta que también abordaré, y que creo que todo historiador debe hacerse cuando decide introducir las imágenes como fuentes históricas y se encuentra ante tanta variedad y complejidad como la que se ha dado en la etapa contemporánea: ¿Cómo podemos entender las imágenes?

En este texto planteo cuatro cuestiones: a) analizar históricamente las imágenes hoy en un tiempo de densa iconosfera digital; b) entender las fricciones culturales que han tenido con la cultura escrita desde su eclosión en la sociedad de las masas; c) comprender algunos de los enfoques divergentes en cuanto a las estrategias metodológicas de su análisis historiográfico, especialmente de las imágenes fotográficas por el peso de su propia apariencia de veracidad; y d) finalmente, una pregunta nada sencilla: ¿Qué son realmente las imágenes y cómo las podemos entender desde la historia? A todas esas cuestiones intentaré dar algunas respuestas en los apartados siguientes en la convicción de que mis aportaciones son sugerencias de trabajo, reflexiones abiertas a la discusión, más que recetas cerradas, dogmáticas y excluyentes, algo que nunca ha formado parte de mi modo de abordar el análisis de las imágenes en su encuentro con la labor histórica. 


\section{LAS IMÁGENES EN LA DENSIDAD DE LA ICONOSFERA DIGITAL: POSICIONES ANTE LAS IMÁGENES DEL PASADO EN UN TIEMPO POSMODERNO}

El término «iconosfera» fue acuñado en 1959 por Gilbert Cohen-Séat y rápidamente adoptado por muchos expertos en comunicación, especialmente Roman Gubern, ${ }^{8}$ que lo ha usado en muchos de sus trabajos. El concepto alude al conjunto de informaciones visuales que circulan desde los medios de comunicación de masas y que conforman una esfera de referencia de significaciones visuales, llegando a sustituir a la propia realidad natural. Cada época histórica ha tenido una iconosfera específica y adaptada a su tiempo cultural y tecnológico. Por ejemplo, para una persona de la Edad Media se trataba de una esfera iconográfica muy leve frente a la realidad cotidiana vista y experimentada, y se componía fundamentalmente de algunas imágenes piadosas contempladas en la iglesia o en espacios concretos. Las estampas aumentaron esa presencia visual de las representaciones, pero la eclosión de la sociedad de las masas a comienzos del siglo XX fue haciendo más y más extensa y compleja la composición de la iconosfera, y la aparición de las tecnologías digitales y los sistemas de telecomunicación personales desde comienzos del siglo XXI han creado unas sociedades de "opulencia visual» donde la apariencia de lo representado prima decisivamente sobre la propia realidad. En 1967, Guy Debord ya advirtió sobre las consecuencias de las nuevas premisas culturales que se estaban configurando a las que denominó en su libro La sociedad del espectáculo y en la que, según sus palabras: «Allí donde la realidad se transforma en simples imágenes, las simples imágenes se transforman en realidad». ${ }^{9}$ Posteriormente Umberto Eco explicó muy acertadamente las consecuencias de la cultura de masas que pensada para el ocio y el disfrute

\footnotetext{
${ }^{8}$ Roman Gubern es una figura reconocida e indiscutible en el campo de la Historia de las Imágenes y sus múltiples interrelaciones con la cultura y la sociedad. Sus trabajos parten de una perspectiva comunicativa siempre rica en significados por las extensas conexiones culturales que despliega en sus análisis. Es difícil resumir en una sola obra el trabajo del profesor Gubern. Su último libro, Roman Gubern, Dialectos de la Imagen (Madrid: Cátedra, 2017), es un excelente ejemplo de su conocimiento de las imágenes en su encuentro con lo humano. Un análisis de conjunto de su obra puede verse en Javier Gurpegui Vidal, «El ojo que piensa. Una cartografía temática de Román Gubern», Con-Ciencia Social 11 (2007): 57-78, y Javier Gurpegui Vidal y Jesús Ángel Sánchez Moreno, «La imagen en sus laberintos. Entrevista con Román Guben», Con-Ciencia Social 11 (2007): 79-108.
}

${ }_{9}$ Guy Debord, La société du espectacle (París: Editions Gallimard, 1967). 
solo intenta "captar el nivel superficial de nuestra atención ${ }^{10}$ y años más tarde Jean Braudillard, explicaba cómo las representaciones, en tanto que simulacros, precedían a lo representado, logrando que perdieran su valor de referencia. ${ }^{11}$

Todos esos mimbres han ido trenzando la sociedad «hipervisiva» en la que ahora habitamos, plena de imágenes que aparecen, se exhiben fugazmente y se borran a toda prisa para dar paso a otras que parecen nuevas. Un continuum en el que la ficción y la realidad parecen tener idénticas naturalezas, en las que entramos y salimos de continuo de las experiencias reales y virtuales, en el que lo objetivo y lo subjetivo parecen tener la misma matriz y cuesta diferenciarlas, y en la que, ensimismados con las nuevas tecnologías de telecomunicación que nos acompañan, estamos esperando lo nuevo que parezca diferente a pesar de que esa supuesta novedad, una vez contemplada y consumida, nos damos cuenta qué forma parte de lo mismo que ya conocíamos.

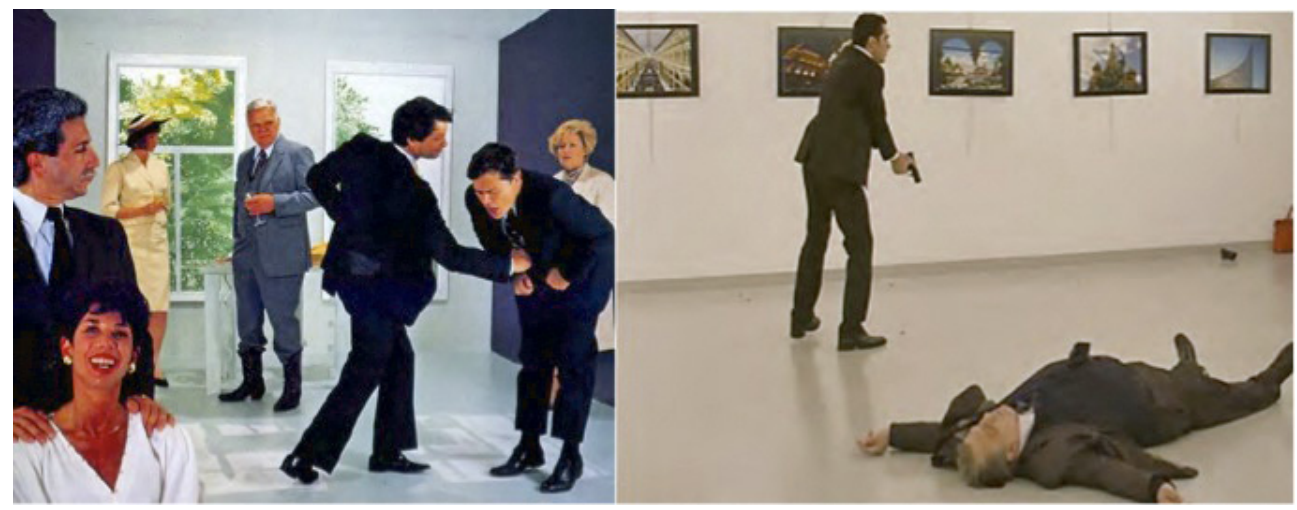

Imágenes 2 y 3. Nic Nicosia. Violencia (1986). Las propuestas posmodernas de los artistas en ocasiones anticipan situaciones que luego se presentan reales, como el asesinato del embajador ruso en Turquía en 2016. Un perfecto ejemplo de la hibridación entre realidades construidas e información inmediata de una sociedad hipervisiva que consume y borra acontecimientos de modo continuado.

\footnotetext{
${ }^{10}$ Umberto Eco, Apocalípticos e integrados (Barcelona: Lumen, 1965). La idea de la «cultura de superficie» que proviene de la abundancia de los medios de masas se ha hecho mucho más evidente en la actualidad con la hegemonía de las prácticas culturales digitales, donde se discute de todo contando tan solo con lecturas muy superficiales.
}

11 Jean Braudrillard, Cultura y simulacro (Barcelona: Ed. Kairós, 1993). 
Un historiador que trabaja hoy con imágenes del pasado tiene que entender también qué significan en estos momentos, qué cambios en su recepción y comprensión se han producido, ante la evidencia de que la sociedad las entiende de un modo muy diferente a como se contemplaron y se percibieron en el momento de su producción y recepción social. Asistimos ahora a unos desplazamientos históricos tanto en sus significados como en sus funciones, que debemos conocer y sobre todo tener en cuenta para no caer en el error del presentismo. Hoy las imágenes apenas se contemplan, tan solo se capturan o sirven de fondo para el ego personal; basta visitar un museo y contemplar la forma en la que los espectadores se fotografían ante las pinturas de otras épocas, generalmente devenidas en iconos culturales, o cómo registran con sus dispositivos móviles, sin apenas mirarlas ni intentar entenderlas, las piezas que el tiempo ha depositado en sus salas.

Vivimos en un tiempo de exceso de imágenes que sin embargo cada vez apreciamos menos. Joan Foncuberta, en un ensayo sobre las imágenes fotográficas en la sociedad digital, que ya se conocen por diversos autores como «posfotografías» reflexionaba al respecto:

Parece obvio que padecemos una inflación de imágenes sin precedentes. Esta inflación no es la excrecencia de una sociedad tecnificada, sino más bien el síntoma de una patología cultural y política, en cuyo seno irrumpe el fenómeno posfotográfico. ${ }^{12}$

Estamos en un tiempo de encrucijada en la que se están conformando otras formas de entender el pasado que tienen una enorme influencia a través de las redes sociales, y que son muy disruptivas para nosotros. Un buen ejemplo es el caso tan celebrado de aquel estudiante de un instituto de educación secundaria norteamericano, Joe Bush, que tuvo varios millones de visitas a su video colocado en youtube, montado a base de unir una serie de imágenes que parecen explicar toda la historia del mundo en tan solo dos minutos, ${ }^{13}$ desde el supuesto comienzo de la gran explosión inicial hasta 2012, año de su producción, entendiendo que la

\footnotetext{
12 Joan Foncuberta, La Furia de las Imágenes: Notas sobre la postfotografía (Barcelona: Galaxia Gutenberg, 2016).

13 Este celebrado trabajo de un alumno de educación secundaria norteamericano sobre la supuesta "Historia en dos minutos», puede verse en la siguiente dirección web: https://www.youtube.com/ watch?v=E_KTq5Z0id4
} 
apariencia visual explica perfectamente los fenómenos históricos, y que todos los ingredientes que componen el discurso historiográfico que explican las razones y motivaciones de los hechos acaecidos no son ya necesarios para dar sentido a los acontecimientos, ya que el pasado y sus significaciones pueden reducirse a una sucesión de imágenes ordenadas con una cierta coherencia en el mejor discurso fragmentado de base posmoderna que puede hacerse, y que las redes sociales, constructoras de las culturas actuales, aplauden, amplifican y estimulan. Son las mismas redes sociales que pueden prohibir la foto de la niña desnuda quemada por el napalm en la guerra de Vietnam, obviando así el carácter de denuncia que la información gráfica jugó en aquel conflicto, y borrando la historicidad al sentido de unas imágenes de ese tipo, convertidas en posfotográficas y alteradas en sus significaciones una vez que circulan por Internet. Ese es uno de los retos actuales de un historiador que trabaja con imágenes del pasado: entender los nuevos escenarios dominantes en las culturas de las redes sociales que están mutando no solo las prácticas culturales con las imágenes, sino también las funciones y valores que han tenido en su devenir histórico y que es necesario seguir explicando. De ahí la importancia de la contextualización de los textos visuales, y su inserción en los imaginarios culturales que se dieron en el momento en el que la imagen estudiada fue producida y que, sin duda, tienen escasa relación con los valores y creencias que ahora se están instituyendo.

\section{FRICCIONES CULTURALES CON LAS IMÁGENES EN EL DESARROLLO DE LA SOCIEDAD DE LAS MASAS}

Comenzaba mi texto diciendo que hoy no parece existir discusión en el hecho de que las imágenes forman parte del discurso historiográfico, pero durante décadas han permanecido ajenas a esa posibilidad, más allá de su funcionalidad como ilustraciones de los textos. Todavía recuerdo como a comienzos de los años noventa, cuando comenzaba mis trabajos sobre las imágenes como fuentes históricas, me encontraba con muchos recelos y la evidencia de que los profesionales formados en el texto escrito se encontraban con muchas dificultades para analizarlas porque carecían de instrumentos para ello, y cuando intentaban entender algunos de los trabajos existentes, se encontraban ante disciplinas muy dispares que no siempre encajaban en el trabajo historiográfico. 
Volveré con detalle en el apartado siguiente a esta cuestión; ahora me gustaría analizar algunas de las razones históricas por las que las imágenes han estado fuera del interés de los trabajos académicos durante tanto tiempo más allá de la historia del arte, que solo ha atendido, dentro de su epistemología, a un repertorio limitado de las mismas. Se trata de un fenómeno internacional que tiene que ver con el propio desarrollo de la sociedad de las masas a comienzos del siglo XX.

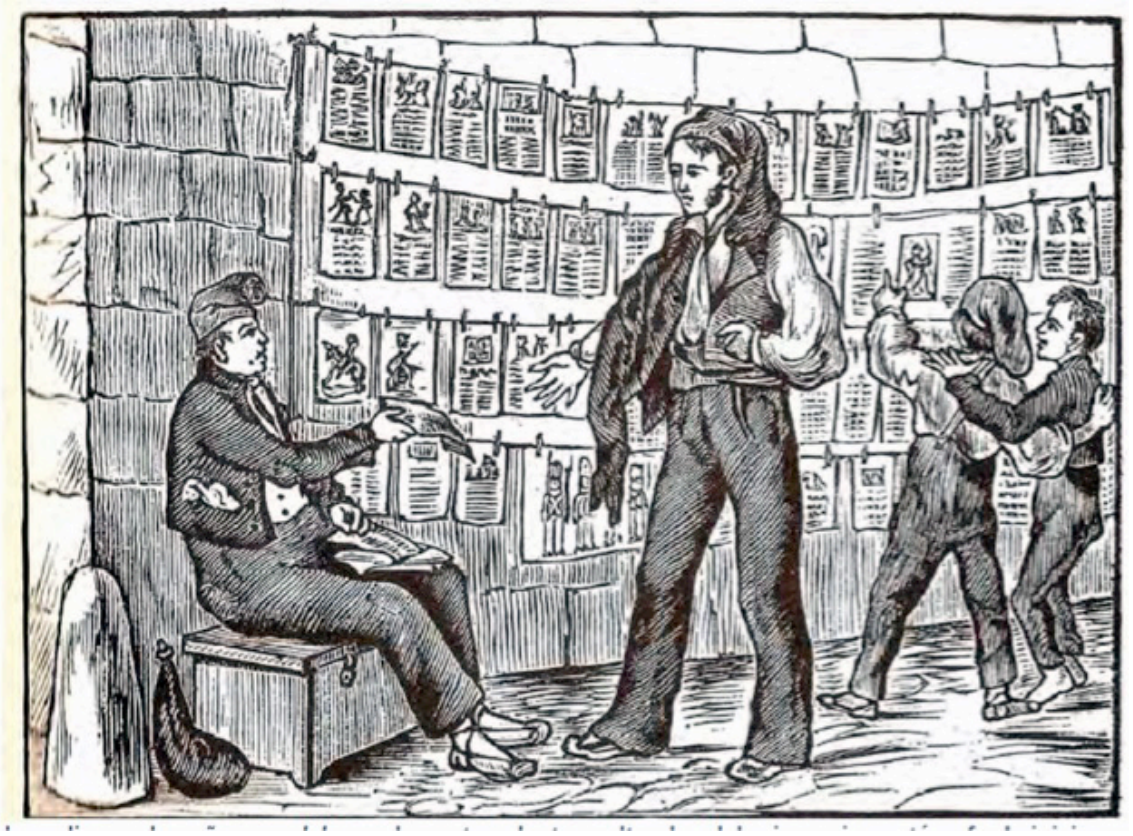

Imagen 4. Los pliegos de caña y cordel son los antecedentes culturales del primer cinematógrafo de inicios del siglo XX. Ambos se dirigían a un público popular con contenidos adaptados a sus gustos, lo que generará una visión despectiva de la alta cultura, centrada de modo excluyente en el texto escrito. (Grabado catalán de 1850 mostrando un local de este tipo de literatura con imágenes impresas).

Como ha ocurrido con Internet, que es un producto del siglo XXI, pero que sus posibilidades se hicieron visibles a finales del siglo XX, los elementos que configurarán la sociedad de las masas estarán disponibles en el último tercio del siglo XIX. Tal será el caso del fotograbado que en la década de los años ochenta de dicho siglo comienza a introducirse en la prensa en diversas tecnologías que se irán depurando, y el 
cinematógrafo que, si atendemos a los dos modelos, el de visión privada de Edison será viable a partir de 1892 y el de la proyección colectiva de los hermanos Lumière se presentará a finales de 1895. Pero su desarrollo se producirá en el siglo XX con la confluencia de la segunda revolución industrial, las economías de escala, un descenso notable de los índices de analfabetismo, una preocupación de los estados por la educación como medio de lograr ciudadanos preparados y competitivos para la economía industrial — lo que dará lugar a una educación estandarizada-, y unos medios de comunicación que ensancharán sus temáticas, apareciendo la prensa de masas, que a diferencia de la decimonónica, su mayor interés será aumentar la venta de ejemplares, lo que le llevará a la búsqueda de temas variados y que conecten con los gustos de una sociedad que está cambiando y se percibe de ese modo moderna respecto a las prácticas y costumbres del pasado. En el ámbito social aparecen dos fenómenos nuevos que se presentan como disruptivos para la alta cultura: en primer lugar, el cinematógrafo que, tras los primeros y breves momentos de exhibición cientifista, presentado como un logro de la "fotografía en movimiento", comienza a ser disfrutado por las clases populares en espectáculos de barraca, lo que plantea críticas e intentos de control por las autoridades eclesiásticas y gubernamentales en cuanto a los contenidos. Al mismo tiempo, aparecen los «magazines», unas revistas donde el texto cada vez tiene menos presencia en detrimento de las fotografías impresas que ganan espacio y muestran por sí mismas lo más relevante de los contenidos informativos. Es fácil entender cómo para muchas personas con escasa cultura alfabética, el ver lo que ocurre en el mundo a través de las películas de las barracas, o que las fotografías impresas les muestren la realidad de su tiempo sin apenas esfuerzo de lectura, constituye en sí mismo un atractivo inédito al que se rinden inmediatamente con el consiguiente escándalo de la alta cultura que no contaba con estas nuevas vías de conocimiento popular y las detestan profundamente. En el caso español, un buen ejemplo lo tenemos en José Ortega y Gasset que claramente no entiende la sociedad de las masas, ni la percibe como un elemento positivo, y así lo refleja en su colección de artículos en el diario El Sol en 1926, que serán compilados para su obra La rebelión de las masas; lo mismo ocurre con la lectura, frente a los nuevos productos culturales y superficiales de la sociedad de las masas. La lectura es para Ortega una práctica sublime e incomparable: 
La lectura en su más noble forma, constituye un lujo espiritual; no es estudio, aprendizaje, adquisición de noticias útiles para la lucha social. Es un virtual aumento y dilatación que ofrecemos a nuestras germinaciones interiores, merced a ella conseguimos realizar lo que solo como posibilidad latía en nosotros. ${ }^{14}$

Esa visión idealizada de la lectura para la alta cultura, contrasta con las prácticas reales que hacen las clases más populares que han encontrado en el naciente cinematógrafo una vía de satisfacción que conecta con la tradición de los pliegos de cordel, un atajo para la lectura y un desdén para toda la cultura establecida que no les interesa frente a la liviandad de una prensa pletórica de imágenes, y de unas películas en las que se reconocen muy bien sus gustos sencillos y populares. Junto a estas tendencias, la prensa y el naciente cine documental resaltan el carácter objetivo de estas tecnologías, mitificando la condición notarial de los reporteros y camarógrafos. La batalla contra el cine popular fue muy exacerbada y los intentos de control y censura de sus contenidos por los estamentos conservadores fueron muy fuertes y han sido bastante estudiados por los historiadores del primer cinematógrafo. ${ }^{15}$ No solo los contenidos estaban en cuestión, también la entrada de niños a las barracas, o se advertía del daño a la vista que el centelleo de las imágenes animadas en las pantallas producía en las mujeres trabajadoras. En 1913, cuando más arreciaban las críticas contra el nuevo medio, una revista especializada defendía precisamente la conexión popular que el nuevo espectáculo tenía:

Alguien ha dicho que el cinematógrafo desaparecerá. El pueblo lo quiere y ya es una necesidad. El poseerlo no es un pasatiempo es algo que le pertenece como el aire que respira, como el sol, es su elemento espiritual, es su poesía. [...] El cinematógrafo es del pueblo y nadie podrá ya quitárselo. ${ }^{16}$

\footnotetext{
14 José Ortega y Gasset, El espectador (Madrid: s.e, 1917), 99. Habrá una nueva versión en 1925 editada en Madrid por Revista de Occidente.

15 Destaco dos trabajos esenciales sobre este tema del primer cinematógrafo: Emeterio Díez Puertas, Historia Social del Cine en España (Madrid: Ed. Fundamentos, 2003), y el más reciente de Vicente J. Benet, El cine español. Una historia cultural (Barcelona: Paidós Comunicación, 2012).

16 Anónimo, «SM el Cine», El Mundo Cinematográfico 18 (1913): 3.
} 
Aunque intelectuales como José Ortega y Gasset cambiarán su visión sobre el cinematógrafo, incorporando críticas de cine en su revista Espa$\tilde{n} a$, este cambio tendrá lugar por el propio proceso de transformación del espectáculo cinematográfico desde las barracas populares a las salas de cine. Los denominados palacios del cine o Picture Palaces, que se construirán en todas las grandes ciudades en detrimento de los teatros, "aburguesaran» las condiciones de exhibición frente a las caóticas formas y las prácticas poco refinadas del primer cine primitivo en unos lugares de exhibición, que además eran muy peligrosos por el carácter inflamable de las películas exhibidas.

Si es evidente que el cinematógrafo se presentó en sus primeros momentos, a partir de 1895, como una conquista científica, la de «la fotografía en movimiento», pasadas las primeras exhibiciones con ese sentido, el espectáculo se convirtió en algo muy popular asociado a los espectáculos de "varietés» y fue consumido preferentemente por las capas más proletarias. Las propias condiciones de exhibición con un «explicador» que hacia comprensible las imágenes que salían proyectadas y cambiaba el sentido narrativo en muchas ocasiones, en unas salas de proyección en las que se hablaba, se fumaba y se comía por parte de los espectadores, hacían que el espectáculo cinematográfico de los primeros tiempos se entendiese como algo vulgar y muy alejado de las normas sociales de otros espectáculos culturalmente más consolidados como el teatro. En este sentido, el trabajo de Juan Carlos de la Madrid, ${ }^{17}$ circunscrito a Asturias, puede extrapolarse al modo general de exhibición del cine primitivo en España y su primera ubicación social. La prensa de la época destaca ese carácter caótico y popular de las barracas de cine y los primeros espectáculos audiovisuales entre los que podríamos incluir hasta las exhibiciones de pantallas de Rayos $\mathrm{X}$ muy populares en ciudades como Barcelona y coincidentes con los años del comienzo del cinematógrafo. Esa percepción, popular e irrelevante es la que se retiene en los años siguientes como indicadora de que los espectáculos visuales no tienen la profundidad cultural e intelectual que sí tiene, en contraposición, lo que proviene de la cultura escrita, y creará una visión respecto a la cultura audiovisual que se impondrá, que está llena de prejuicios. Unas prevenciones que pasarán también al medio televisivo, denominado

17 Juan Carlos de la Madrid, Cinematógrafo y «Varietes» en Asturias. 1896-1915 (Oviedo: Servicio de Publicaciones del Principado de Asturias, 1996). 
como una especie de "caja tonta» porque procede de la misma raíz audiovisual —que no tecnológica— que el cinematógrafo.

Un buen ejemplo lo tenemos en la influyente revista La Gaceta Ilustrada que a comienzos de 1956 aludía en un a lo perjudicial que era la televisión cuando todavía faltaban unos meses para sus primeras emisiones en España.

El historiador de la educación y de los media británico David Buckinham, ha estudiado el mismo proceso en Gran Bretaña, y las mismas resistencias que allí se dieron al estudio y la comprensión de los nuevos medios de masas, y que explican porque todos estos fenómenos fueron ignorados por los medios académicos durante muchos años:

En un principio, al menos, la enseñanza de la cultura popular se veía como una extensión de este enfoque [...]. En su libro, Culture and Environment: The Training of Critical Awareness (1933), el famoso crítico literario F.R. Leavis y su estudiante Denys Thompson presentaron el primer conjunto sistemático de propuestas para la enseñanza en medios de comunicación de masas en la escuela, centrándose principalmente en periodismo, narrativa popular y publicidad. Consternados por la modernidad, Leavis y sus seguidores rememoraban la imaginada armonía de la «comunidad orgánica» preindustrial. [...] Leavis observaba la herencia literaria como una manera de defenderse ante el declive social y ponía sus esperanzas en una pequeña elite cultural asediada; si bien también mantenía que había que pasar a la ofensiva en educación. La enseñanza de la cultura popular podría ayudar a los estudiantes a «discriminar y resistir», a armarse contra la manipulación comercial y los placeres superficiales de los medios de masas y, por consiguiente, a reconocer lo que él veía como los méritos evidentes de la alta cultura. ${ }^{18}$

\footnotetext{
18 David Buckinham, «La evolución de la educación mediática en Reino Unido: algunas lecciones de
} la historia». Revista interuniversitaria de formación del profesorado 82 (2015): 77-88. 


\section{\begin{tabular}{|l} 
La \\
televisión \\
puede \\
ser \\
perjudicial
\end{tabular}}
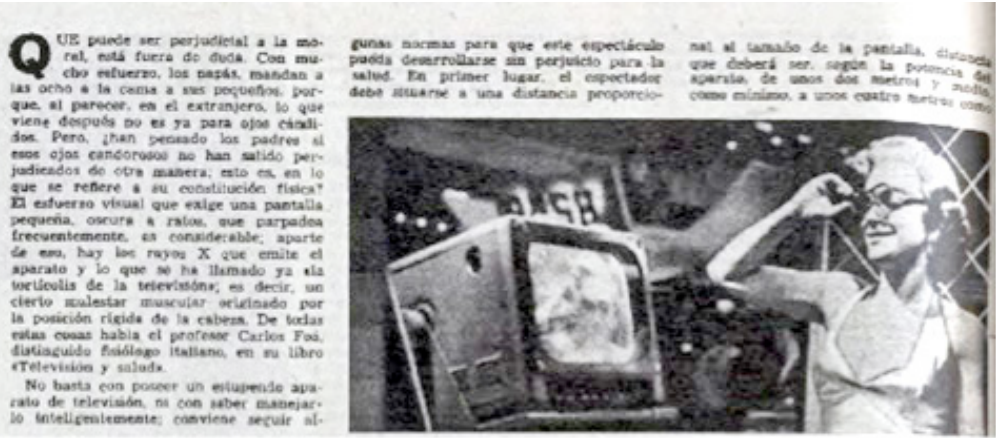

Imagen 5. Los medios de masas posteriores al cinematógrafo también sufrieron esa visión despectiva de los ambientes culturales. Esta noticia sobre la televisión y sus supuestos problemas la publicó la influyente revista La Gaceta Ilustrada

en enero de 1956, varios meses antes de que apareciera en España la televisión. Es un reflejo de esa tendencia sobre los media y sus carencias que han persistido hasta la actualidad prácticamente.

La realidad es que, a pesar de los prejuicios las resistencias y los olvidos, resulta hoy imposible obviar a los medios de la sociedad de masas para entender lo que ha sido el siglo XX o fenómenos como la fotografía y la prensa gráfica o el cartelismo desde el siglo XIX, además de otros aspectos menos conocidos como los numerosos espectáculos ópticos que desembocaron en el cinematógrafo y que atravesaron varios siglos de cultura europea. Las linternas mágicas y otros espectáculos conformaron a un nuevo espectador que mutará en el siglo XX con los medios de masas, cuyas expectativas y experiencias ante las imágenes nos permiten ahora entender algo del valor y del alcance de sus significados sociales y culturales. Las tecnologías de la comunicación que se instituyeron desde comienzos del siglo XX, fueron conformando toda una nueva ideología de la realidad en la que los dispositivos fotográficos y cinematográficos eran «certificados de neutralidad», y sobre esa aparente presencia «notarial» de las imágenes, los fotógrafos y los camarógrafos fueron desarrollando nuevas narrativas visuales que ahora necesitamos explorar y poner en evidencia en el trabajo histórico, más allá de la apariencia de lo que representan que no es más que la primera capa de análisis y comprensión de estos documentos visuales que ayudaron culturalmente a construir toda una nueva época. 


\section{ENFOQUES DIVERGENTES EN TORNO A LAS ESTRATEGIAS METODOLÓGICAS DEL ANÁLISIS DE LAS IMÁGENES}

De toda la diversidad iconográfica que nos ha dejado la etapa contemporánea, sin duda hay una tipología que presenta un interés especial. Las fotografías, aparecidas en 1839 con nombres inicialmente tan extraños como daguerrotipo o calotipo, aludiendo a los primeros inventores francés y británico, son imágenes sin precedentes en la historia cultural. Nunca en el pasado, la química, la física y la óptica combinadas habían dado un producto visual como este, unas imágenes que se concibieron desde sus orígenes como una copia exacta de la realidad, como un fragmento congelado y perenne del tiempo, que mostraba algo que había ocurrido exactamente de ese modo, sin que hubiese lugar a dudas o a la visión subjetiva de la mano del dibujante o del pintor sobre la escena. Daguerre, el primer inventor francés, lo enunció de modo muy preciso cuando explicaba que la nueva tecnología de imágenes era «la propia naturaleza reproduciéndose a sí misma». ${ }^{19}$

Las imágenes fotográficas tienen un enorme interés para los historiadores porque combinan ese elemento de veracidad indiscutible en lo que muestran con el hecho de que se han conservado miles y miles, por no decir millones, desde el siglo XIX y son una fuente visual imprescindible. En el caso español desde la década de los años ochenta del siglo XX se ha dado todo un movimiento en torno a la revalorización cultural de la fotografía que ha culminado, por el momento, con un imprescindible y monumental trabajo para entender su historia y su devenir en el tiempo, obra de Carmelo Vega aparecido a finales de 2017. ${ }^{20}$ Desde 1981, en un esfuerzo colectivo, han ido publicándose diversas monografías y estudios en torno a la historia de la fotografía, de muy diversa factura e interés metodológico pero que han conformado una primera cartografía de los temas, autores e imágenes que la componen, y en ese sentido una de las primeras preocupaciones que hemos tenido algunos de los que hemos impulsado esta historiografía, ha sido analizar su genealogía, el origen, las posiciones y los cambios que se han producido en

\footnotetext{
19 Sobre las condiciones de percepción cultural y tecnológica de la fotografía en 1839, y la recepción universitaria en España, véase Bernardo Riego, La Introducción de la Fotografía en España. Un reto científico y cultural (Girona: Ediciones CRDI, 2000).

${ }^{20}$ Carmelo Vega, Fotografía en España (1839-2017), historia, tendencias, estéticas (Madrid: Manuales de Arte Cátedra, 2017).
} 
torno a la forma de entender la propia historia de la fotografía a lo largo del tiempo.

Sin desviarnos demasiado del interés central de este apartado, una de las cuestiones más llamativas sobre la historia de la fotografía es que se trata de una especialidad que ha cambiado su propio objeto de estudio e incluso la epistemología que tuvo a lo largo del siglo XIX. Todavía en 1932, Josef Maria Eder, el historiador de referencia de la primera etapa, publicaba la última revisión de su gigantesca Geschichte der Photographie, aparecida en 1905. ${ }^{21}$ Para Eder, como para los historiadores que le precedieron, lo único de interés y el objeto histórico de la fotografía, eran sus avances en química, física, óptica o nuevos procesos técnicos, pero en ningún modo las imágenes que no formaban parte de sus preocupaciones. Y este modelo historiográfico tenía una poderosa razón para trabajar así; como hemos visto, durante gran parte del siglo XIX había muchas dificultades para reproducir las fotografías en las páginas impresas con su aspecto tonal; por eso, cuando en 1937, en un momento ya de madurez de las técnicas de fotograbado en todo el mundo, el Museum of Modern Art (MOMA) de Nueva York expuso por primera vez en sus salas una exposición fotográfica, el catálogo editado de la misma, titulado Photography 1839-193722 dedicó la evolución de la historia fotográfica no a sus avances técnicos, sino a las imágenes que se habían producido desde el momento de la invención. Beaumont Newhall, el comisario de la muestra, hacia entrar así la fotografía en los museos y utilizó para su tratamiento museográfico los mismos métodos de descripción conocidos en historia del arte, de tal modo que a partir de ese momento, y en iniciativas posteriores como la de Raymond Lecuyer en 1945 para la fotografía francesa, la historia de la fotografía era la historia de sus imágenes y a los avances técnicos se les asignaba un papel siempre secundario. La fotografía fue, desde entonces, una rama más o menos reconocida de la historia del arte; el propio MOMA separó en 1938 las colecciones fotográficas que tenía de su sección de estampas y

\footnotetext{
${ }^{21}$ El libro de Josef Maria Eder aún sigue contando ediciones en el mundo anglosajón, aunque ya no tiene vigencia historiográfica. Una de las últimas es Josef María Eder, History of Photography (New York: Dover Publications, 1978). La edición original inglesa de su libro en alemán publicada en 1945 en la misma editorial Dover, puede consultarse on line en https://archive.org/details/EderHistoryPhotography.

${ }^{22}$ Este catálogo, hoy pieza de coleccionistas, puede consultarse en línea en una digitalización de muy buena calidad en: https://monoskop.org/images/5/52/Photography_1839-1937_MoMA_1937.pdf
} 
grabados, creando una sección propia de las que el mismo Newhall y luego Edward Steichen fueron sus conservadores iniciales.

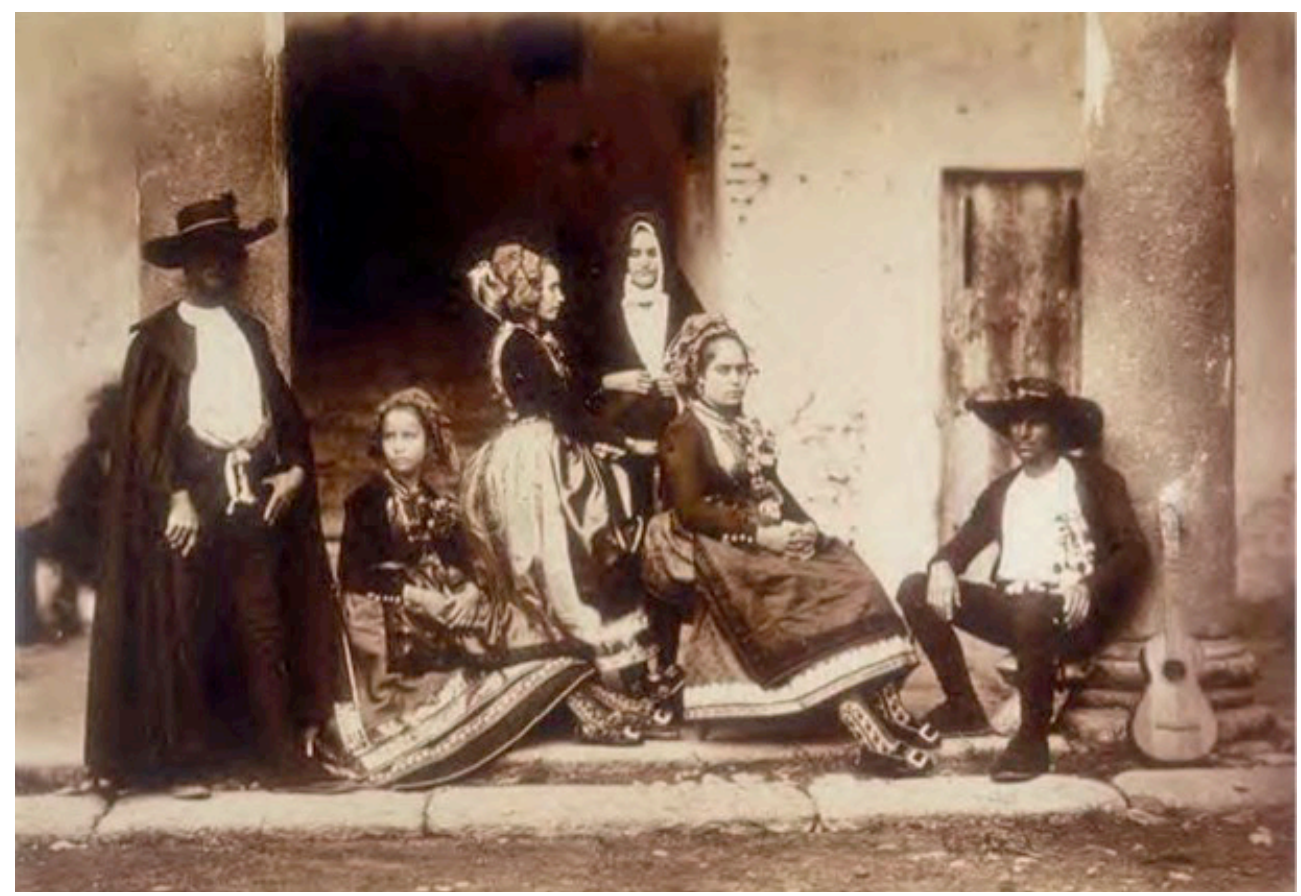

Imagen 6. Charles Clifford. Tipos locales españoles (1858). Según el enfoque historiográfico esta imagen fotográfica es una creación artística de un autor británico singular, o una respuesta más o menos estandarizada del negocio internacional de las imágenes románticas españolas dentro de la tendencia cultural y comercial de la época por parte de viajeros europeos.

El modelo historiográfico creado por Newhall tuvo una vigencia de décadas en todo el mundo y fue el que recibimos en España en la década de los años ochenta cuando se inició aquí el proceso de revalorización cultural de la fotografía. Cuando lo recibimos entre nosotros, era ya una escuela agotada epistemológicamente y así lo advertimos varios autores que escribimos sobre sus insuficiencias. Muy recientemente, en un monográfico publicado en la revista Fotocinema, de la Universidad de Málaga, ${ }^{23}$

\footnotetext{
23 Javier Marzal y Bernardo Riego, «Miradas Convergentes. La Fotografía y sus interpretaciones en Humanidades y Ciencias Sociales», Fotocinema. Revista científica de cine y fotografía 10 (2015). (Consultado el 25-01-2019). URL: http://www.revistafotocinema.com/index.php?journal=fotocinema\&page $=$ issue $\&$ op $=$ view $\&$ path $\% 5 \mathrm{~B} \% 5 \mathrm{D}=25$
} 
Carmelo Vega volvía a recordar cuáles eran los puntos débiles de una historiografía que solo buscaba rellenar un panteón de obras y autores, excluyendo los contextos culturales de producción y recepción de las imágenes fotográficas y al servicio del mercado del arte internacional:

Buena parte de las historias de la fotografía están impregnadas de los intereses [...] del reconocimiento y puesta en valor de determinadas colecciones fotográficas. Por ejemplo, una gran parte de la historia de Gernsheim está basada en su propia colección, que había sido adquirida por la Universidad de Texas, en Austin. Y muchos trabajos de Newhall, implicaban el reconocimiento y difusión de las colecciones de aquellas instituciones para las que trabajó (Museum of Modern Art, Georges Eastman House). A pesar de defender el carácter internacional de toda investigación sobre historia de la fotografía y de utilizar materiales fotográficos procedentes de colecciones francesas e inglesas, Newhall reconoció el carácter chauvinista de sus trabajos afirmando que los fotógrafos más importantes procedían de Estados Unidos. ${ }^{24}$

Si durante unas décadas el modelo historiográfico, de origen norteamericano, de asociar las imágenes fotográficas y sus autores con parámetros de la historia del arte tuvo su vigencia, a comienzos de la década de los años sesenta se abrió una nueva vía de indagación que tendrá una enorme influencia posterior. En 1961, el situacionista Roland Barthes, publica un artículo titulado «el mensaje fotográfico», que ya no se preocupa por los valores estéticos de las imágenes fotográficas, sino por sus modos de comunicar. Es el tiempo de auge de la semiótica estructural, y pronto comienzan a aparecer con Roland Barthes conceptos de análisis inéditos al entender que las imágenes formaban parte de un sistema de signos, que tenían varios planos de significación como el Studium y el Punctum y que toda imagen fotográfica era un "índice», es decir, una huella de que había existido un fenómeno real del que era referencia. Barthes abrirá toda esta vía en el texto de 1961, todavía impreciso, pero muy influyente desde el primer momento porque abordaba las potencialidades comunicativas de las imágenes fotográficas, una cualidad evidente a la que los estudios artísticos no sabían dar respuesta:

\footnotetext{
${ }^{24}$ Carmelo Vega, «Un modelo sin modelo. Repensar la historia de la fotografía en España», Fotoci-
} nema. Revista científica de cine y fotografía 10 (2015): 57-74. 
¿Cuál es el contenido del mensaje fotográfico? ¿Qué es lo que transmite la fotografía? Por definición, la escena en sí misma, lo real literal. Hay, ciertamente, una reducción al pasar del objeto a su imagen: de proporción, de perspectiva y de color. Pero en ningún momento esa reducción llega a ser una transformación (en el sentido matemático del término); para pasar de lo real a su fotografía, no hace ninguna falta segmentar lo real en unidades y constituir estas unidades en signos sustancialmente diferentes al objeto que permiten leer; entre el objeto y su imagen no es en absoluto necesario disponer de un intermediario, es decir, un código; claro que la imagen no es real, pero, al menos, es el analogón perfecto de la realidad, y precisamente esta perfección analógica es lo que define la fotografía delante del sentido común. Y así queda revelado el particular estatuto de la imagen fotográfica: es un mensaje sin código. De esta proposición se hace imprescindible deducir de inmediato un corolario importante: el mensaje fotográfico es un mensaje continuo..$^{25}$

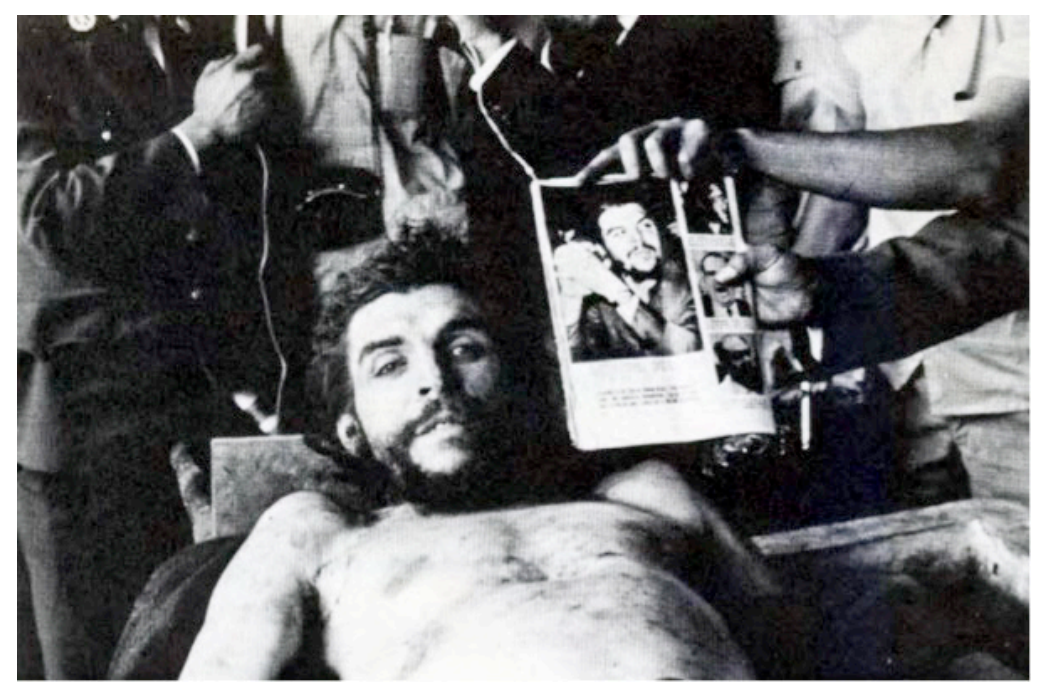

Imagen 7. Freddy Alborta. La prueba de la prueba. El ejército boliviano muestra el cadáver del Che Guevara a la prensa en Valle Grande Bolivia 11 de octubre de 1967, en la mejor tradición semiótica en la que una imagen contiene a otra en su propia estructura informativa.

25 Roland Barthes, «Le message photographique», Communications 1, no. 1 (1961): 127-138. El texto puede consultarse en: https://monoskop.org/images/a/a5/Barthes_Roland_le_message_photographique_1961.pdf 
En los años siguientes los estudios de comunicación que partían de los análisis semióticos colonizaron el análisis de la fotografía; algunos de sus postulados siguen teniendo vigencia actualmente en los ámbitos académicos de comunicación audiovisual, aunque los conceptos que se utilizan encajan bastante mal con el tiempo histórico. En este sentido, han sido los estudios culturales los que han permitido un análisis más contextual de las imágenes en el campo de la historia al que se han ido sumando otras disciplinas de humanidades y ciencias sociales que aproximan el documento fotográfico a otros matices que lo enriquecen sustancialmente. En 2015, como dije anteriormente, en la Universidad de Málaga a través de su revista Fotocinema, hicimos un intento de aproximar las diversas visiones que se estaban produciendo en torno a los documentos fotográficos en diversas especialidades, contemplando las nuevas posiciones semióticas, pero también desde la antropología o la sociología. El resultado del monográfico reveló la pluralidad de posiciones existentes que finalmente dan más valor a las imágenes fotográficas, pero también hacen más complejos los análisis a quienes desde la historia desean aproximarse a unas fuentes que parecen tan evidentes por su apariencia. Destaco de entre todas las aportaciones que se hicieron en el monográfico un breve fragmento del profesor Andrés Davila Legerén desde el campo de la sociología:

Conviene traer a colación los planteamientos del paleontólogo Stephen Jay Gould y su insistencia en que deberíamos ser conscientes de las consecuencias de la elaboración y circulación de cada imaginería. Al respecto, Gould expresaba su apuro cuando en distintas ocasiones que había acudido a dar alguna conferencia «ante un grupo de humanistas» se había encontrado «en salas sin pantalla y sin posibilidad de cubrir las ventanas», o en las que ni tan siquiera había proyector, mientras que las diapositivas eran «indispensables» para su exposición; una situación que había visto reproducida incluso tratándose de «charlas humanísticas sobre temas explícitamente visuales», a las que había asistido muy sorprendido ante el hecho que casi en ninguna de ellas «se mostró una sola imagen», llevándole todo ello a preguntarse acerca de «¿por qué los científicos comprenden la importancia de las imágenes mientras que la mayoría de los humanistas acepta sin más la hegemonía de la palabra?». En el terreno de 
las humanidades, las publicaciones académicas desprecian por lo general la imaginería de muy diversas maneras. [...] Pero las imágenes son vitales para nosotros. [...] Muchos de nuestros juicios acerca de cuestiones sociales, especialmente nuestras emociones, están basados en imágenes [...] Desde el punto de vista académico es mucho lo que se puede aprender del estudio de la imagen (incluso de su desprecio). ${ }^{26}$

El resultado de tantas aproximaciones que en modo alguno deseo relatar de modo exhaustivo, nos lleva a la necesidad de tener un conocimiento previo, aunque sea mínimo, de cuál es la posición del texto que analiza o usa fotografías con el que nos encontramos, porque, aunque parece existir un punto de partida unívoco en los análisis, lo cierto es que tal cosa no se da en realidad. La cuestión se hace mucho más compleja como consecuencia de la recepción, sobre todo en los estudios teóricos de Bellas Artes, de las corrientes posmodernas que siguen las concepciones de Jean-François Lyotard y que niegan la condición de relato científico a la propia historiografía en la que trabajamos de modo tradicional. En algunas de las tesis doctorales a las que he acudido como miembro del tribunal evaluador en Bellas Artes me he encontrado con algunas visiones que si no se entiende su origen pueden parecer del todo contraproducentes. Las posiciones posmodernas se han ido introduciendo en España a través de trabajos que en el ámbito de la crítica fotográfica norteamericana se han hecho muy influyentes en algunos círculos, ${ }^{27}$ y que es necesario entender desde su propia conceptualización porque en una primera lectura tensan mucho las propias tradiciones historiográficas que dan sentido a la fotografía. Un buen ejemplo lo constituye el libro de Geoffrey Batchen, Arder en deseos: la concepción de la fotografía, aparecido en 2004, que comienza por negar la propia historicidad en los análisis del medio fotográfico e intenta construir un punto de partida totalmente nuevo:

La historia fotográfica lleva siempre consigo el proceso de su propia desaparición. Un singular punto de origen, un significado definitivo, una narrativa lineal: todos estos objetos históricos

\footnotetext{
${ }^{26}$ Andrés Davila Legerén. «A la luz de la propia sombra. Incorporaciones de la fotografía a la sociología», Fotocinema. Revista científica de cine y fotografía 10 (2015): 285-326.

${ }_{27}$ Especialmente un libro que recoge una serie de artículos editados por Jorge Ribalta con artículos adscritos a esta línea interpretativa: Jorge Ribalta, Efecto real, debates posmodernos sobre fotografía (Barcelona, Gustavo Gili Ediciones, 2004).
} 
tradicionales se desplazan de ahí en adelante de la procedencia de la fotografía. En su lugar, hemos descubierto algo mucho más provocativo: una forma de repensar la fotografía que coincide persuasivamente con la innegable complejidad conceptual, política e histórica del medio fotográfico. ${ }^{28}$

Es evidente que el uso de las imágenes fotográficas como fuente histórica tiene un recorrido en el tiempo no demasiado largo si lo comparamos con las fuentes textuales, y que se hace necesario partir de premisas muy rigurosas para insertarlas en el discurso historiográfico, pero mi experiencia personal me hace pensar que hay un extenso territorio de análisis y de trabajo en torno a la comprensión de las imágenes, que hemos estado demasiado sometidos a recetas cerradas, como fue el caso de la semiótica, que se revelaron muy insuficientes, y que el repertorio para acometer análisis está muy abierto y en él tiene mucho peso la propia experiencia profesional del historiador. Por eso, me gustaría terminar este texto con una cuarta aportación, más allá de la diversidad de concepciones teóricas y su comprensión conceptual que he señalado en este apartado, que se centra en la propia esencia de las imágenes: unas pocas ideas para tratar de entenderlas desde la propia cultura en la que nos encontramos inmersos y en algunas de las prácticas y condiciones que serían recomendables trabajando con las representaciones visuales que se constituyen en fuentes históricas por la voluntad, la experiencia y la labor del historiador.

\section{¿CÓMO DEBEMOS ENTENDER LAS IMÁGENES Y CÓMO PODEMOS USARLAS?}

A lo largo del tiempo las imágenes han adoptado infinidad de formas y formatos, prácticamente se han reproducido en todos los soportes imaginables, y cada una de las representaciones en función de su técnica presenta una estructura en trazos o puntos que la hacen reconocible y catalogable, pero más allá de esa primera capa especializada, es evidente que las imágenes son productos ligados a nuestra cultura, construcciones sociales que están vinculadas al poder y a los intereses de quien detenta y puede difundir la información. Aunque por las razones que hemos comentado más arriba se las ha considerado frecuentemente

\footnotetext{
${ }_{28}$ Geoffrey Batchen, Arder en deseos: la concepción de la fotografía (Barcelona: Gustavo Gili Ediciones, 2004): 203.
} 
como objetos artísticos, lo cierto es que también han tenido otras muchas funciones sociales y la imprenta ha sido una de las difusoras más importantes de las imágenes en nuestra cultura reciente de los últimos siglos. Las prensas de imprenta han producido textos de muy diversos tipos, pero también estampas y a partir del último tercio del siglo XIX las imágenes impresas con aspecto tonal fotográfico que, como ya hemos visto, son el origen de nuestra iconosfera contemporánea.

Las estampas fueron durante mucho tiempo un producto secundario de la cultura artística. Si nos acercamos a muchos de los estudios en torno al grabado publicados en el tiempo, vemos que atendían sobre todo a sus cuestiones estéticas y de autoría, pero en 1953 apareció un importante libro del conservador de estampas del MOMA, William M. Ivins, Jr., que reivindicó su importancia social, su influencia y sus funciones en la propia comprensión de la realidad: «Las estampas, lejos de ser simplemente obras de arte de segunda fila, constituyen una de las herramientas más importantes y poderosas de la vida y el pensamiento modernos».29

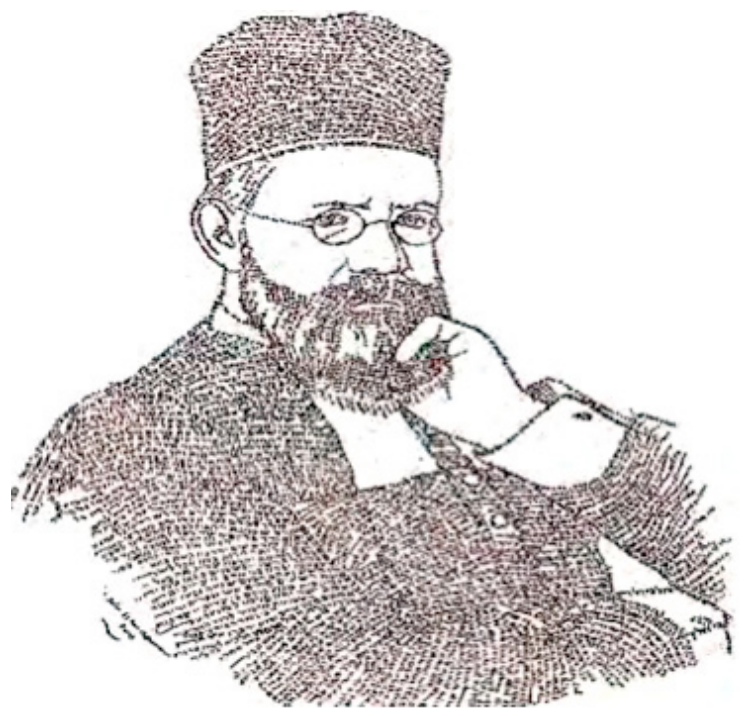

Imagen 8. Retrato micrográfico del rabino Mosés Gaster. Hacia 1890. Es un texto que parece una imagen y de este modo burla el tabú icónico. Las letras parecen letras y eso es lo que son, auténticos caligramas. Un buen ejemplo de la pulsión humana ante las representaciones.

\footnotetext{
${ }_{29}$ William M. Ivins Jr., Prints and Visual Comunication (1953). Edición española: Imagen impresa y
} conocimiento. Análisis de la imagen prefotográfica (Barcelona: Gustavo Gili, 1975). 
Hoy sabemos que la fotografía desde un punto de vista tecnológico sustituyó a las estampas en la visión de la realidad cotidiana, y de algún modo las primeras visiones de las planchas metálicas de cobre donde se registraban las primeras imágenes fotográficas eran tenidas como nuevas formas de grabado que recordaban a las planchas de los aguafuertes. Otra de las cuestiones poco conocidas, pero que las actas de la invención de la fotografía que se conservan en la Academia de Ciencias de París revelan, era que el plan inicial de la multiplicación de las imágenes fotográficas pasaba porque las planchas fotográficas daguerrotípicas se convirtieran en una suerte de matrices, algo que no se logró, y durante décadas la fotografía tuvo que buscar otros circuitos de difusión hasta que el fotograbado pudo resolver de modo efectivo el problema de la reproducción fotográfica en las páginas impresas.

Pero las imágenes presentan también características que las liga a la parte más etológica de lo humano, a pesar de que algunas religiones las restringen por el denominado "tabú icónico», las propias culturas han inventado medios para saltarse la prohibición, como los caligramas micrográficos hebreos. En la cultura cristiana (y no es exclusivo del cristianismo porque se manifiesta en muchas otras sociedades) se les atribuyen poderes mediadores o sustitutos de la presencia divina, relaciones intangibles que activan a muchas personas que creen en su eficacia sobrenatural. David Freeberg en su documentado libro sobre la relación de las imágenes con las personas lo expresa de modo muy explícito:

Las personas se excitan sexualmente cuando contemplan pinturas y esculturas. Las rompen, las mutilan, las besan, lloran ante ellas y emprenden viajes para llegar hasta donde están; se sienten calmadas por ellas, emocionadas e incitadas a la revuelta. Con ellas expresan agradecimiento, esperan sentirse elevadas y se transportan hasta los niveles más altos de la empatía y el miedo. 30

\footnotetext{
${ }^{30}$ Freedberg, El poder de las imágenes, 19.
} 


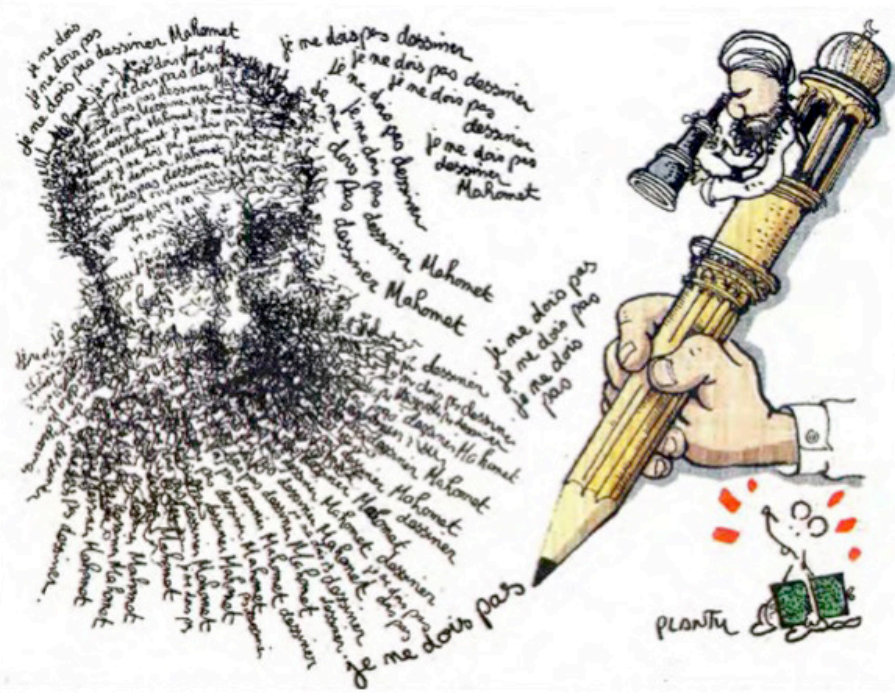

Imagen 9. Una utilización política del tabú icónico. Imagen publicada en el diario El País el 3-XII-06 con motivo de la polémica por la publicación en un diario danés de la imagen de Mahoma.

Pero para un historiador las imágenes deberían ser ante todo textos visuales que tienen que ser explorados en sus contextos de producción y de recepción, analizando la cadena institucional que las crea y las hace posibles, porque a diferencia de los textos que en muchos casos cuentan su propia historia por la edición, autoría y otros elementos editoriales, muchas de las imágenes no lo hacen y es necesario comprender cuestiones en torno a su propia producción, difusión y recepción, incluyendo los «imaginarios» vigentes en el momento de su creación que nos pueden dar a entender algunas cuestiones de fondo. Desde luego, el autor que firma la fotografía o cualquier imagen no es sino el eslabón último de toda una toma de decisiones que pueden estar ligadas al mero comercio, a un encargo concreto con características ideológicas, porque el medio de publicación puede condicionar la propia construcción visual de la imagen, o a una iniciativa personal, como las que hacen los aficionados, pero enmarcada en el contexto de unas creencias compartidas. Pongo un ejemplo de esto último: en las colecciones de imágenes fotográficas de aficionados de comienzos del siglo XX aparecen con mucha frecuencia fotografías de las nuevas costumbres que se están configurando, 
junto a imágenes de pescadores o personas del mundo rural en sus tareas tradicionales o de otras actividades que se están volviendo anticuadas ante el empuje de la modernidad. Esa tensión entre lo moderno y lo tradicional que captan invariablemente muchas de esas colecciones fotográficas, nos lleva a la cuestión generalizada de la percepción de un mundo que está en transformación y que la sensibilidad del aficionado capta, lo mismo que hace una figura consagrada como Federico García Lorca cuando exalta el mundo del Romancero Gitano, o se estremece con la incomprensión de lo que es una megalópolis en su Poeta en Nueva York. Es relativamente sencillo explorar el imaginario de la modernidad en películas, textos literarios y fotografías de aficionados de aquel momento, una tarea contextual que explican con acierto María del Mar del Pozo Andrés y Teresa Rabazas en un texto reciente:

El uso de la imagen como documento histórico implica un cuidadoso estudio y critica externa de las fuentes, del origen de lo que se ha dado en llamar «el archivo visual», pues la forma en la que se construyó dicho archivo condiciona la intencionalidad del fotógrafo y el tipo de información que se puede conseguir. ${ }^{31}$

Es cierto que, gracias a la archivística, las colecciones de imágenes están cada vez mejor organizadas, catalogadas y contextualizadas, y es posible indagar en la persistencia de temáticas que se repiten a lo largo del tiempo, hitos visuales que se repiten en el tiempo, porque en el fondo estamos ante una industria de las imágenes que hace producciones que sabe muy bien lo que puede comercializar con una cierta garantía de éxito. Un historiador que trabaje con imágenes en sus discursos historiográficos tiene que intentar superar la estanqueidad metodológica en la que todos nos hemos formado. Las imágenes forman parte de una estructura cultural compartida y, a poco que se indague, las cuestiones que muestran aparecerán en otras fuentes contadas de modos diversos: la experiencia del historiador manejando fuentes visuales le lleva enseguida a ensanchar su mirada más allá de las mismas o de la mera autoría.

\footnotetext{
31 María del Mar del Pozo Andrés y Teresa Rabazas Romero, «Las imágenes fotográficas como fuente para el estudio de la cultura escolar. Precisiones conceptuales y metodológicas», Revista de Ciencias de la Educación 231-232 (2012): 401-414.
} 
Me gustaría terminar este texto con una última idea que en otras ocasiones he denominado el "paradigma Chambi», porque es un ejemplo que demuestra muy bien una característica inherente a las imágenes que también desde la tarea historiográfica debemos tener en cuenta. En comunicación visual se la denomina el problema de las «instancias productoras y receptoras», pero creo que es más adecuado referirnos a ella como «las múltiples miradas» en relación con los tiempos históricos. Cuando miramos una imagen, además de reconocer lo que muestra, activamos nuestros saberes en torno a su significado y ponemos en ella una serie de certezas que inevitablemente son de nuestro tiempo. Es una posición que no podemos obviar, pero sí que tenemos que tener en cuenta que la forma de contemplar la imagen y de entender sus significados generalmente no concuerda con el pensamiento de quienes la contemplaron en el momento de su producción. La percepción «especular» de una fotografía para un espectador del siglo XIX no opera en un espectador del siglo XX para el que las imágenes son ante todo «escritura personal» y no reproducción mecánica de la realidad gracias a la conjunción de la óptica, de la física y de la química. El mejor ejemplo de las múltiples miradas construidas en el tiempo lo tenemos en la obra del fotógrafo peruano Martín Chambi, un fotógrafo de la localidad de Cuzco de la primera mitad del siglo XX donde hacía fotografía social de todo tipo que ahora es la obra con la que se le reconoce internacionalmente gracias al trabajo de recuperación de Luis de Toledo que dio lugar en la década de los años noventa a una espléndida monografía de la obra de Chambi. ${ }^{32}$ Pero entre todas las hermosas imágenes de la sociedad cuzqueña que registraron sus placas, hay una que pone en evidencia el artificio de la recuperación cultural del fotógrafo peruano. Martín Chambi, autor de su tiempo, se sentía también artista de la fotografía y presentaba su obra artística en salones y exposiciones. Hacia 1930 se retrata ante una exposición con sus obras y llama la atención que lo que él considera su labor fotográfica no son las imágenes que le han llevado al éxito actual, sino que las temáticas a las que se dedica, que coinciden con el salonismo de la época, nada tienen que ver con ellas, porque eran tan solo su modus vivendi, su trabajo profesional muy diferenciado de lo que él expone como su labor creadora y artística, algo que en estos momentos no tiene ningún interés cultural y que si fueran las de su exposición las

32 Luis de Toledo, Martín Chambi 1920-195 (Barcelona: Lunwerg Editores, 2002). 
que se mostraran, no explicarían su éxito como fotógrafo de un tiempo concreto. Antonio Viñao ha puesto de manifiesto la importancia de los tiempos que sin duda deben formar parte también de la indagación de las imágenes para evitar los riesgos del presentismo:

El tiempo social y humano, múltiple y plural, es un aspecto más de la construcción social de la realidad. Esta construcción es consecuencia e implica el establecimiento de unas determinadas relaciones entre el antes, el después y el ahora [...] de una determinada temporalización de la experiencia en relación con un presente también concreto. En este sentido, el tiempo es una relación no un flujo, una facultad humana específica [...] Una facultad de síntesis y relación que, junto con la memoria, crea y conecta el espacio de la experiencia y el horizonte de expectativas. ${ }^{33}$

Trabajar con imágenes resulta una experiencia muy gratificante para un historiador porque le ensancha los límites de su campo de trabajo; no son materiales ajenos a la cultura en las que la investigación del pasado se mueve. Como el resto de las fuentes que manejamos, precisan de unas estrategias metodológicas, de unas aproximaciones conceptuales diferentes que en gran medida están por consolidar como he intentado explicar a lo largo de este texto. Ya hemos visto que las visiones rígidas y las recetas cerradas que en el pasado han operado sobre el análisis iconográfico han terminado por quedarse obsoletas. En mi opinión, esta casi todo por hacer y por indagar y hay territorio para explorar; un territorio en el que hay que adentrarse sin prejuicios, pero con las precauciones evidentes que todo historiador siempre tiene cuando analiza el pasado. En este sentido, los pensamientos de Peter Burke cierran este breve paso por las cuestiones que hoy nos interpelan a quienes trabajamos con fuentes visuales. Bienvenidos al nuevo territorio de las imágenes que siempre han estado ahí, esperándonos:

Ni que decir tiene que el uso del testimonio de las imágenes plantea numerosos problemas harto delicados. Las imágenes son testigos mudos y resulta difícil traducir a palabras el testimonio que nos ofrecen. [...] La crítica de los testimonios visuales sigue

\footnotetext{
33 Antonio Viñao, «Historia de la educación e historia cultural: posibilidades, problemas, cuestiones», Revista de Educación 306 (1995): 245-269.
} 
estando muy poco desarrollada, aunque el testimonio de las imágenes, como el de los textos, plantea problemas de contexto, de función, de retórica, de calidad del recuerdo... ${ }^{34}$

\section{Nota sobre el autor}

Bernardo Riego Amézaga es profesor de Tecnología Educativa y Comunicación Audiovisual en el Departamento de Educación de la Universidad de Cantabria, y doctor en Historia Contemporánea. Es un experto en Historia Cultural de las Imágenes y del Patrimonio Audiovisual, especialmente del fotográfico, a la vez que autor de varios libros y multitud de artículos sobre estas temáticas. En el año 2001 fue comisario en la Fundación Marcelino Botín de la Exposición «Memorias de la Mirada» que intentó ser una reflexión sobre las Tecnologías de la Comunicación en España desde el siglo XVIII a la llegada del cine mudo y su impacto social y cultural.

Uno de sus ámbitos centrales de investigación se refiere a la Historia de la Fotografía, especialidad en la que ha publicado varios libros entre los que destacan La introducción de la Fotografía en España. Un Reto Científico y Cultural (2000) y La Construcción Social de la Realidad a Través de la Fotografía y el Grabado Informativo en la España del Siglo XIX (2001). Recientemente ha sido editor y coautor del libro España en la tarjeta postal. Un Siglo de Imágenes (2011) en el que se reivindica el papel de los materiales culturales efímeros como la tarjeta postal ilustrada para la comprensión del siglo XX.

Forma parte del grupo de investigación sobre orígenes del cine en España, desarrollando un proyecto I+D del Ministerio de Educación en torno a «Presencias y representaciones de la mujer en el cine de los orígenes» (HAR2015-66262-P). También colabora como investigador en el proyecto Europeo «A million pictures. Magic Lantern slide heritage as artefacts in the common european history of learning» (PCIN-2015-186).

Muchos de los textos que tiene publicados pueden consultarse y descargarse en su blog bernardoriego.wordpress.com

\footnotetext{
34 Burke, Visto y no visto, 18.
} 


\section{REFERENCIAS}

Barthes, Roland. La cámara lúcida. Nota sobre la Fotografía. Barcelona: Paidós 1989.

Barthes, Roland. «Le message photographique». Communications 1, no. 1 (1961): 127-138.

Batchen, Geofrey. Arder en deseos: la concepción de la fotografía. Barcelona: Gustavo Gili Ediciones, 2004.

Benet, Vicente J. El cine español. Una historia cultural. Barcelona: Paidós Comunicación, 2012.

Braudrillard, Jean. Cultura y simulacro. Barcelona: Ed. Kairós, 1993.

Buckinham, David. «La evolución de la educación mediática en Reino Unido: algunas lecciones de la historia». Revista interuniversitaria de formación del profesorado 82 (2015): 77-88.

Burke, Peter (ed.). Formas de hacer historia. Madrid: Alianza Ensayo, 2003.

Burke, Peter. Visto y no visto. El uso de la imagen como documento histórico. Barcelona: Crítica, 2001.

Castells, Manuel. La sociedad red: una visión global. Madrid: Alianza Ensayo, 2006.

Davila Legerén, Andrés. «A la luz de la propia sombra. Incorporaciones de la fotografía a la sociología». Fotocinema. Revista científica de cine y fotografía 10 (2015): 285-326.

Debord, Guy. Comentarios sobre la sociedad del espectáculo. Barcelona: Anagrama, 1999.

Debord, Guy. La société du espectacle. París: Editions Gallimard, 1967.

De la Madrid, Juan Carlos. Cinematógrafo y «Varietes» en Asturias. 1896-1915. Oviedo: Servicio de Publicaciones del Principado de Asturias, 1996.

De Toledo, Luis. Martín Chambi 1920-195. Barcelona: Lunwerg Editores, 2002.

Del Pozo Andrés, María del Mar y Teresa Rabazas Romero. «Las imágenes fotográficas como fuente para el estudio de la cultura escolar. Precisiones conceptuales y metodológicas». Revista de Ciencias de la Educación 231-232 (2012): 401-414.

Díez Puertas, Emeterio. Historia social del cine en España. Madrid: Ed. Fundamentos, 2003.

Eco, Umberto. Apocalípticos e integrados. Barcelona: Lumen, 1965.

Eder, Josef Maria. History of Photography. New York: Dover Publications, 1978. Foncuberta, Joan. La furia de las imágenes: Notas sobre la postfotografía. Barcelona: Galaxia Gutenberg, 2016.

Freedberg, David. El poder de las imágenes. Madrid: Cátedra, 1992.

Gombrich, Ernst. Gombrich esencial. Madrid: Debate, 1999.

Gubern, Roman. Dialectos de la Imagen. Madrid: Cátedra, 2017. 
Gurpegui Vidal, Javier. «El ojo que piensa. Una cartografía temática de Román Gubern». Con-Ciencia Social 11 (2007): 57-78.

Gurpegui Vidal, Javier y Jesús Ángel Sánchez Moreno. «La imagen en sus laberintos. Entrevista con Román Gubern». Con-Ciencia Social 11 (2007): 79108.

Haskell, Francis. La historia y sus imágenes. El arte y la interpretación del pasado. Madrid: Alianza Forma, 1993.

Ivins Jr., William M. Imagen impresa y conocimiento. Análisis de la imagen prefotográfica. Barcelona: Ed. Gustavo Gili, 1975.

Marzal, Javier y Bernardo Riego. «Miradas Convergentes. La Fotografía y sus interpretaciones en Humanidades y Ciencias Sociales». Fotocinema. Revista científica de cine y fotografía 10, no, 2. (2015). URL: http://www.revistafotocinema.com/index.php?journal=fotocinema\&page $=$ issue \&op=view \&path $\% 5 \mathrm{~B} \% 5 \mathrm{D}=25$

Ortega y Gasset, José. El Espectador. Madrid, s.e., 1917.

Ribalta, Jorge. Efecto real, debates posmodernos sobre fotografía. Barcelona, Gustavo Gili Ediciones, 2004.

Riego, Bernardo. La construcción social de la realidad a través de la fotografía y el grabado informativo en la España del siglo XIX. Santander: Ediciones UC, 2001.

Vega, Carmelo. Fotografía en España (1839-2017) historia, tendencias, estéticas. Madrid: Manuales de Arte Cátedra, 2017.

Vega, Carmelo. «Un modelo sin modelo. Repensar la historia de la fotografía en España», Fotocinema. Revista científica de cine y fotografía 10 (2015): 57-74.

Viñao, Antonio. "Historia de la educación e historia cultural: posibilidades, problemas, cuestiones». Revista de Educación 306 (1995): 245-269. 